\title{
Selective foraging by fish-eating killer whales Orcinus orca in British Columbia
}

\author{
John K. B. Ford ${ }^{*}$, Graeme M. Ellis \\ Fisheries and Oceans Canada, Pacific Biological Station, 3190 Hammond Bay Road, Nanaimo, British Columbia V9T 6N7, Canada
}

\begin{abstract}
As the apex non-human marine predator, the killer whale Orcinus orca feeds on a wide diversity of marine fauna. Different ecotypic forms of the species, which often exist in sympatry, may have distinct foraging specialisations. One form found in coastal waters of the temperate NE Pacific Ocean, known as the 'resident' ecotype, feeds predominantly on salmonid prey. An earlier study that used opportunistic collection of prey remains from kill sites as an indicator of predation rates suggested that resident killer whales may forage selectively for chinook salmon Oncorhynchus tshawytscha, the largest but one of the least abundant Pacific salmon species. Potential biase in the prey fragment sampling technique, however, made the validity of this finding uncertain. We undertook field studies of foraging behaviour of resident killer whales to resolve this uncertainty and to examine potential variation in prey selection by season, geographical area, group membership and prey availability. Foraging by resident killer whales was found to frequently involve sharing by 2 or more whales. Prey fragments left at kill sites resulted mostly from handling and breaking up of prey for sharing, and all species and sizes of salmonids were shared. Resident killer whale groups in all parts of the study area foraged selectively for chinook salmon, probably because of the species' large size, high lipid content, and year-round availability in the whales' range. Chum salmon Oncorhynchus keta, the second largest salmonid, were also taken when available, but smaller sockeye $O$. nerka and pink O. gorbuscha salmon were not significant prey despite far greater seasonal abundance. Strong selectivity for chinook salmon by resident killer whales probably has a significant influence on foraging tactics and seasonal movements, and also may have important implications for the conservation and management of both predator and prey.
\end{abstract}

KEY WORDS: Prey choice $\cdot$ Food sharing $\cdot$ Foraging specialisation $\cdot$ Salmonid predation Resale or republication not permitted without written consent of the publisher

\section{INTRODUCTION}

Marine mammals that occupy high trophic positions in marine ecosystems can have important top-down effects on those ecosystems (Bowen 1997). As the apex (non-human) marine predator, the killer whale Orcinus orca is capable of preying on a great variety of species and has a remarkably diverse diet. The list of prey taken by this cosmopolitan predator includes more than 120 species of fishes, cephalopods, sea turtles, sea birds, mustelids, pinnipeds and cetaceans (Martinez \& Klinghammer 1970, Jefferson et al. 1991, Matkin \& Saulitis 1994, Fertl et al. 1996, Similä et al. 1996, Ford et al. 1998). With such a diversity of prey types, killer whales can potentially influence ecosystem structure and function at a variety of levels. For example, it has recently been proposed that predation by killer whales caused the depletion of several marine mammal populations in the North Pacific in the post-whaling era (Springer et al. 2003). A variety of arguments have been raised against this hypothesis (e.g. DeMaster et al. 2006, Mizroch \& Rice 2006), which emphasise how much uncertainty exists regarding the dynamics of killer whales and their prey. Developing an understanding of the factors involved in prey selection, as well as the extent of foraging specialisation or flexibility, will be needed if we are to better understand the roles played by killer whales in marine ecosystems. Such knowledge is also important for conservation of both killer whale populations and their prey.

Although a generalist as a species, different killer whale populations can have strikingly divergent foraging specialisations. For example, in coastal waters of the NE Pacific Ocean, 2 sympatric, genetically-distinct killer 
whale ecotypes, so-called 'residents' and 'transients', feed almost exclusively on fish and marine mammal prey, respectively (Bigg et al. 1990, Baird \& Dill 1995, Ford et al. 1998, 2000, Hoelzel et al. 1998, Ford \& Ellis 1999, Barrett-Lennard 2000). Killer whale populations in other regions, such as Norway, Argentina and Antarctica, also specialise on particular prey types, and often employ elaborate foraging tactics in order to do so (Lopez \& Lopez 1985, Similä \& Ugarte 1993, Baird 2000, Pitman \& Ensor 2003). Such specialisations appear to represent behavioural traditions that are passed across generations by social learning (Guinet \& Bouvier 1995, Ford et al. 1998, Saulitis et al. 2000), and have been described as cultures (Rendell \& Whitehead 2001).

Behavioural traditions may determine the overall type of prey that is acceptable to a particular killer whale population and the foraging tactics employed for prey capture, but other factors are likely to play important proximate roles in prey selection. Prey choice by predators is influenced by rates of encounters with a prey species and its profitability, which is determined by the prey item's net energy value and the amount of time needed to catch and handle it (Stephens \& Krebs 1986, Scheel 1993, Bowen et al. 2002). Factors that are important in prey choice in killer whale populations are poorly known, but longterm studies in the NE Pacific have provided some insights. Mammal-hunting transient killer whales in this region prey on at least 9 species of marine mammals, including seals, sea lions, porpoises, dolphins and baleen whales, but appear to prefer small species such as harbour seals Phoca vitulina and harbour porpoises Phocoena phocoena, which are common yearround in the whales' range (Haley 1986). These species are relatively easy to capture and kill, and have a low probability of causing injury to the attacking whales (Baird \& Dill 1995, Ford et al. 1998, 2005). Sympatric, fish-eating resident killer whales show movement patterns in nearshore waters that are closely associated with high densities of migrating salmon (HeimlichBoran 1986, Guinet 1990, Nichol \& Shackleton 1996). Nichol \& Shackleton (1996) found positive correlations between the seasonal occurrence of resident killer whales and 3 of the most abundant salmonid species, pink salmon Oncorhynchus gorbuscha, sockeye salmon $O$. nerka and chum salmon O. keta, off NE Vancouver Island, British Columbia. Ford et al. (1998) confirmed that salmonids were the predominant food of resident killer whales in these waters by identifying prey species from scales and tissue fragments collected from kill sites. An unexpected finding, however, was that sockeye, pink and chum salmon, despite being correlated with the occurrence of killer whales in this area, formed the minority of prey samples. Instead, chinook salmon $O$. tshawytscha, one of the least com- mon salmonids during the summer migration period, represented almost two-thirds of prey items identified.

The disproportionate occurrence of chinook salmon in prey samples relative to its low abundance led Ford et al. (1998) to suggest that resident killer whales may forage selectively for this species over other available salmonids. Chinook is the largest salmonid and has a relatively high lipid content, features that may be desirable for foraging killer whales. However, Ford et al. (1998) also raised concerns that potential biases in their prey sampling method may have led to over-representation of chinook and under-representation of other species in samples from predation events. Chief among these was the possibility that chinook, being larger than other salmonids, may be broken up by whales prior to being eaten, thus shedding more scales than smaller salmonids in the process (Ford et al. 1998). However, without knowledge of the details of prey handling and consumption of salmonid and other fish species by resident killer whales, it was not possible to evaluate the significance, if any, of this potential bias. It was concluded that resident whales may have a preference for chinook, but the extent of their selectivity for this species remained uncertain (Ford et al. 1998). These potential biases as well as small sample sizes also prevented Ford et al. (1998) from examining potential differences in prey selection among different resident communities or social groups, as suggested by Nichol and Shackleton (1996), or by different sex or age classes, as suggested by Bain (1989).

In order to address these and other gaps in the current knowledge of resident killer whale diet and prey selection, we undertook field studies of foraging behaviour and feeding by resident killer whales from 1997 to 2005 to build upon the data presented in Ford et al. (1998). In particular, field efforts from 2003 to 2005 were focused on documenting the detailed aspects of prey capture and handling to assess the validity of using prey fragment sampling to interpret dietary preferences. In this report, we present new information on the frequent occurrence of cooperative foraging and prey sharing in resident killer whales, and the implications of this behaviour with respect to the use of prey fragments as indicators of prey selection. Extensive sampling of feeding events also allowed us to evaluate prey selection quantitatively with regard to prey species availability, as well as by geographical location, group membership, and age and sex class of foraging whales.

\section{MATERIALS AND METHODS}

Study area and population. Field studies on the life history, social organisation, acoustic behaviour, and population genetics of killer whales in British Colum- 
bia have been undertaken since 1973 (Bigg 1982, Bigg et al. 1987, 1990, Olesiuk et al. 1990, Ford 1989, Ford et al. 1998, 2000, Barrett-Lennard 2000). These long-term studies have relied extensively on the photographic identification of individuals from natural markings (Bigg et al. 1987, Ford et al. 2000). In these waters, 2 communities of resident killer whales, 'northern residents' and 'southern residents' can be found in all months of the year, but are observed mostly during May to November. The northern resident community is found typically from mid Vancouver Island to SE Alaska, and the southern resident community off the southern half of Vancouver Island and in the inland waters of Washington State. Whales from the 2 communities have not been seen to associate, despite extensive overlap in their ranges (Ford et al. 2000). Large aggregations of resident killer whales can be found in certain coastal locations during summer. The whales greatly reduce their use of these locations in winter and spring, and their range during this period is poorly known (Ford et al. 2000, Wiles 2004). The northern and southern resident communities contained 219 and 87 individuals, respectively, in 2004 (authors' unpubl. data, K. Balcomb, Center for Whale Research, Friday Harbor, Washington, unpubl. data).

The basic social unit of resident killer whales is the 'matriline', which consists of individuals that are closely related by matrilineal descent. Matrilines generally contain an old female, or matriarch, and 1 to 3 generations of her descendents of both sexes. Dispersal of individuals from the matriline is extremely rare (Ford et al. 2000). Matrilines are comprised of an average of 6 members $( \pm 0.59 \mathrm{SE}$, range 1 to $26, \mathrm{n}=50)$. Resident killer whales typically travel in 'pods', which consist of related matrilines that spend the majority of their time together (Bigg et al. 1990). Although some pods originally described in the 1970s and 1980s have maintained their stability, others have split in recent years (Ford et al. 2000). 'Clans' are comprised of pods and matrilines that have descended from a common matrilineal ancestor and have a unique set of shared dialects. The northern resident community consists of 3 clans, A, G, and R, while the southern resident community is made up of a single clan, J. Members of the northern resident clans frequently associate with one another.

Field effort and procedures. Data on predation by resident killer whales in British Columbia have been collected each year since 1974. Data collected from 1974 to 2002 consisted mostly of opportunistic observations of feeding events and collection of prey fragments from the vicinity of kills. Effort varied widely according to changing research objectives, but predation studies were given higher priority after 1990 (Ford et al. 1998, 2000). The results of these studies up to 1996 were reported by Ford et al. (1998), and some of these data are included in the present study. In 2003 to 2005, field studies were dedicated to systematically documenting foraging behaviour and collecting predation data, in addition to conducting the annual census of individuals by photo-identification (Bigg et al. 1987, Ford et al. 2000). A total of 152 field days were devoted to these objectives in 2003 to 2005.

Field studies from 1974 to 2002 were conducted using a variety of vessels from 5 to $20 \mathrm{~m}$ in length. In 2003 to 2005, dedicated focal-individual and focalgroup studies were undertaken mainly from a $10 \mathrm{~m}$ long power vessel. When whales were encountered, individuals were observed visually or photographed to determine the identity of matrilines present. Photographic identification procedures are described in Bigg et al. (1987) and Ford et al. (2000). Once the identity of killer whales present in the encounter was established, effort was directed to documenting foraging behaviour and collecting scales and tissue fragments from prey killed during feeding events. The activity state of the whales was determined from surfacing and dispersion patterns (see Ford 1989 for definitions of activity states). When foraging, whale groups typically spread out over several square kilometres, with individuals and subgroups swimming and diving independently but travelling generally in the same direction. Surfacing whales were observed by eye or binoculars for signs of prey pursuit or capture. When apparent feeding was observed, the site of the kill was approached quickly, while taking care to avoid disturbing the whales, in order to determine identity of the individual(s) involved and to search for prey fragments in the water. Whether or not feeding was confirmed, the individual or subgroup was then followed at distances of 50 to $150 \mathrm{~m}$ to document subsequent feeding events. Focal individuals and subgroups (Altmann 1974, Mann 1999) that were actively feeding were followed for as long as the activity continued or until focal animals joined other groups and could no longer be followed individually.

The behaviour of focal individuals and subgroups was monitored closely and constantly during feeding sessions. Particular attention was given to direction of travel, regularity of dive durations, and extent of subgroup cohesion, as changes in these variables often signalled a feeding event. Individuals or subgroups suspected to have captured a prey item were approached to within $20 \mathrm{~m}$ to observe prey handling and consumption. To collect evidence of feeding, the surfacing locations of the feeding whale or subgroup were also examined for prey fragments at the surface or in the water column. The principal observer, who was also the boat operator, was situated approximately $4 \mathrm{~m}$ above the water surface on the flying bridge of the research vessel. This position afforded a high-angle view 
into the water as the boat was manoeuvred. A second observer stood on the vessel's bow, holding a finemesh dip net (mesh size approximately $1 \mathrm{~mm}$ ) with $4 \mathrm{~m}$ telescoping handle, and also searched for fragments. When fish scales or pieces of tissue were seen, the boat was immediately stopped and the net was deployed to retrieve the fragments. Fragments were collected mostly at depths of 0 to $2 \mathrm{~m}$, but occasionally as deep as 3 to $4 \mathrm{~m}$ in calm conditions with good water clarity. Generally, only a subsample of the many scales and tissue fragments seen in the water were collected from each kill. Rain, winds greater than 10 knots, and high water turbidity reduced the success rate of fragment location and collection. Prey fragments and scales were stored in $10 \mathrm{ml}$ vials containing $95 \%$ ethanol. Until 2004, no effort was made to collect tissue samples from fish kills when scales were available for collection, but both were collected systematically in that year and in 2005. The date, time, and geographical position (from a GPS instrument) of the feeding event was recorded, as well as the identity of the individual making the kill and other whales involved in the prey capture or consumption. If individuals could not be identified, their age/sex class was noted whenever possible.

Prey species identification and ageing. Many species of fishes are readily identifiable at a distance by an experienced observer, but salmon species can be difficult to distinguish without close examination. Although Ford et al. (1998) included salmonid identifications based on field observations, in the current analyses we included only positive species identifications of salmonids based on scales or tissue samples to eliminate this potential source of error. Fish scales were analysed by the Fish Ageing Laboratory at the Pacific Biological Station (Department of Fisheries and Oceans, Nanaimo, British Columbia, Canada) to determine species identity and age. Age was designated using the European method, whereby years in freshwater after hatching and years in marine water are identified and separated by a decimal point (Groot \& Margolis 1991), and age class was assigned according to a standard 1 January birth date. Age class was thus calculated by summing the freshwater and marine years of the European age and adding 1.

Scales that could not be positively identified to species and tissue samples collected from feeding events were submitted to the Molecular Genetics Laboratory at the Pacific Biological Station for species identification using analysis of microsatellite DNA. The methodology of these analyses is described in Withler et al. (2004).

General analyses. Statistical analyses were conducted using SPSS Version 11.0. The significance of differences between 2 group means was tested using Mann-Whitney $U$-tests, and among different frequencies of occurrence by chi-squared $\left(\chi^{2}\right)$ goodness-
Table 1. Orcinus orca. Evidence for 529 kills by resident killer whales documented from 1974 to 2005

\begin{tabular}{|lrr|}
\hline Evidence of predation & No. of kills & $\%$ \\
\hline Observation only & 80 & 15.1 \\
Both tissue and scale samples & 100 & 18.9 \\
Tissue samples only & 21 & 4.0 \\
Scale samples only & 328 & 62.0 \\
Total & 529 & 100 \\
\hline
\end{tabular}

of-fit tests. The standard error (SE) of the mean is given as a measure of variability.

\section{RESULTS}

A total of 529 feeding events were observed during 206 encounters with resident killer whales between 1974 and 2005. Of these, 340 (63\%) were recorded during dedicated feeding studies in 2003 to 2005. Prey samples (tissue or fish scales) were recovered from 449 feeding events $(85 \%)$, while the remaining $15 \%$ were documented by observation only (Table 1). A mean of 4.8 scales per feeding event $( \pm 0.24 \mathrm{SE}$, range 1 to 28 ) were collected from 428 of the 529 feeding events (81\%). During 2004 to 2005, when tissue as well as scales were collected systematically when both were available, tissue fragments were retrieved from 115 of $249(46 \%)$ feeding events.

Feeding events were documented from May to December. A total of $463(87.5 \%)$ feeding events involved northern residents, and 66 (12.5\%) events involved southern residents. All 4 resident clans and all but 1 of the 19 resident pods in the northern and southern communities are represented in this data set (the exception is W1 pod; Ford et al. 2000). Samples were collected from most regions of the coast, but twothirds came from waters off NE Vancouver Island, an important core area for northern residents (Fig. 1, Table 2; see also Ford et al. 2000). Kills made during a total of 274 feeding events could be attributed to whales of known age or sex class. The monthly distribution of these is shown in Table 3.

\section{Foraging behaviour and prey fragment sampling}

Dedicated studies of foraging behaviour of resident killer whales in 2003 to 2005 resulted in sampling 331 feeding events on $60 \mathrm{~d}$. Within this period, focal subgroups or individuals were followed and observed for a total of $61.7 \mathrm{~h}$ during 34 feeding sessions, which we defined as the interval between the first and last feeding events in a series by that individual or subgroup. 
Table 2. Orcinus orca. Species composition of fishes killed in 529 whale feeding events from 1974 to 2005 in different coastal regions of British Columbia (for details see Fig. 1). Species identity of salmonids was determined by scale analysis $(\mathrm{n}=412)$ or from DNA analysis of tissue fragments $(n=20)$. Species identity of non-salmonid fishes was determined from field observation $(n=1)$, scale analysis $(n=2)$, examination of partial carcasses recovered from kills $(n=3)$, and from DNA analysis of tissue fragments $(n=1)$. PFMA: Pacific Fisheries Management Areas of Fisheries \& Oceans Canada; UnSa: salmonids observed as prey in the field but not sampled, or salmonids that could not be identified to species. UnFi: fishes that could not be positively identified to species and could include either salmonids or non-salmonids. QCI: Queen Charlotte Islands. All samples from PFMA Areas 1 to 13 were collected from northern resident killer whales. Samples from PFMA Areas 14 to 29 involved southern resident killer whales, except for the sablefish sample, which was collected from a northern resident killer whale. Of the total 529 feeding events, 135 were included in Ford et al. (1998)

\begin{tabular}{|c|c|c|c|c|c|c|c|c|c|c|c|}
\hline Region & PFMA & $\mathrm{n}$ & $\begin{array}{l}\text { O. tshawytscha } \\
\text { (Chinook) }\end{array}$ & $\begin{array}{l}\text { O. keta } \\
\text { (Chum) }\end{array}$ & $\begin{array}{l}\text { O. kisutch } \\
\text { (Coho) }\end{array}$ & $\begin{array}{l}\text { O. gorbuscha } \\
\text { (Pink) }\end{array}$ & $\begin{array}{c}\text { O. nerka } \\
\text { (Sockeye) }\end{array}$ & $\begin{array}{c}\text { O. mykiss } \\
\text { (Steelhead) }\end{array}$ & Other & UnSa & UnFi \\
\hline North coast and QCI & $1-6$ & 72 & 43 & 17 & 0 & 0 & 0 & 0 & $1^{\mathrm{a}}$ & 10 & 1 \\
\hline \multicolumn{12}{|l|}{ Vancouver Island } \\
\hline NE & $12-13$ & 324 & 177 & 76 & 6 & 12 & 0 & 0 & $2^{\mathrm{b}}$ & 44 & 7 \\
\hline SE & $14-19,28-29$ & 47 & 27 & 2 & 2 & 0 & 1 & 2 & $1^{\mathrm{c}}$ & 10 & 2 \\
\hline$\%$ of identified salmo & nids & & 71.5 & 22.7 & 2.1 & 3.0 & 0.2 & 0.4 & & & \\
\hline \multicolumn{12}{|c|}{$\begin{array}{l}\text { a1 Pacific halibut Hippocampus stenolepis } \\
\text { b1 yelloweye rockfish Sebastes ruberrimus, } 1 \text { herring Clupea pallasi } \\
\text { c1 quillback rockfish } S \text {. maliger } \\
\text { d2 herring C. pallasi, } 1 \text { sablefish Anoplopoma fimbria }\end{array}$} \\
\hline
\end{tabular}

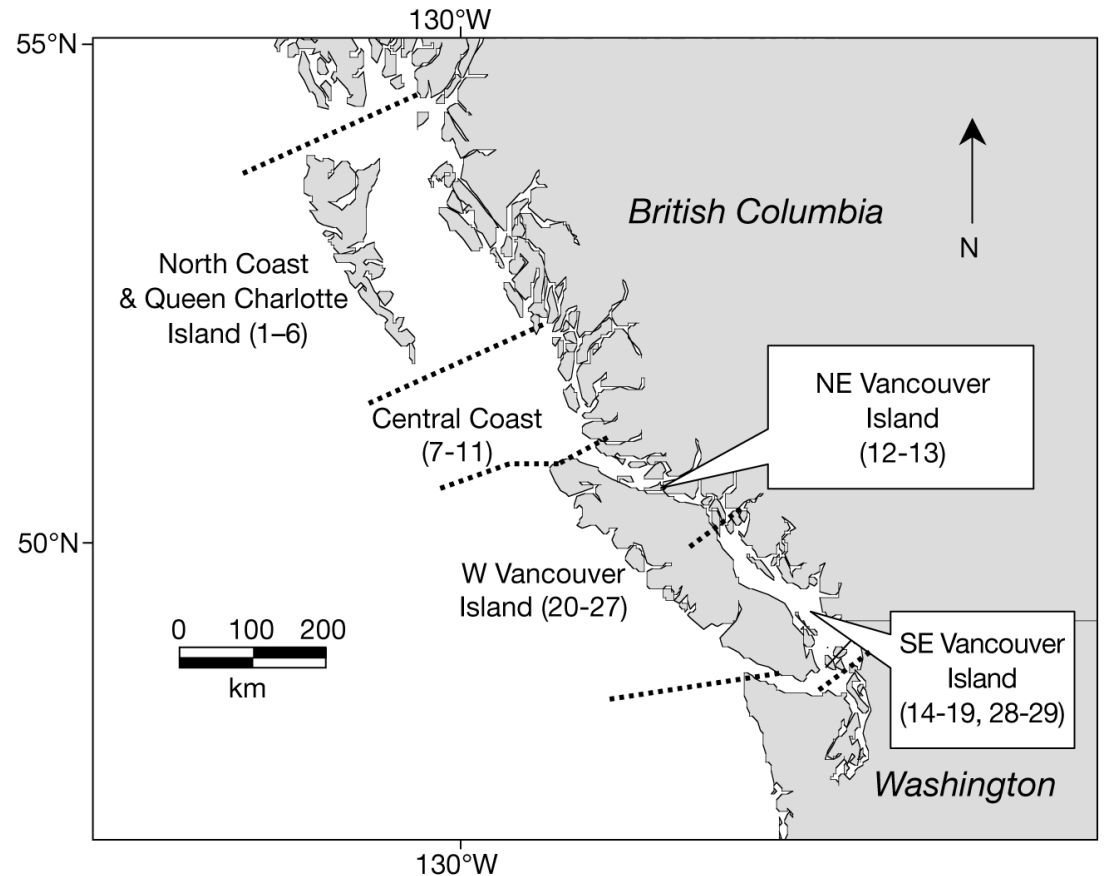

Fig. 1. Coastal regions of British Columbia (Pacific Fisheries Management Area designations). Numbers of Orcinus orca feeding events and prey species identified for each region are shown in Table 2

Feeding sessions by focal individuals and subgroups lasted an average of $1.9 \mathrm{~h}( \pm 0.29 \mathrm{SE}$, range 0.4 to $9.25 \mathrm{~h}$ ). Of the total 331 feeding events, 170 were documented during these 34 sessions, with an average of 5 feeding events per session $( \pm 0.47 \mathrm{SE}$, range 2 to 15$)$.
Intervals between feeding events ranged from 2 to $120 \mathrm{~min}$, with an average of $25.8 \min ( \pm 1.84 \mathrm{SE}, \mathrm{n}=136$ intervals $)$. Almost one-third of feeding events in a session were $10 \mathrm{~min}$ or less apart. Based on the distinct behavioural cues associated with prey capture and consumption, we believe that few feeding events were missed during feeding sessions by focal groups or individuals.

An average of 4.5 matrilines were present during encounters in which feeding behaviour was documented $( \pm 0.37 \mathrm{SE}$, range 1 to 12 matrilines, $\mathrm{n}=60$ encounters). Subgroups, which usually consisted of complete matrilines or partial matrilines comprised of mothers and their young offspring, often foraged $200 \mathrm{~m}$ or more apart. Adult males usually foraged independently or in association with their mother, especially in cases where the mother had no juvenile offspring. Whales often foraged close to shorelines, especially in the deep, narrow channels and straits frequented by resident killer whales during summer and autumn. Adult males usually foraged further offshore than subgroups. Individuals and subgroups foraging nearshore followed the coastline closely, often within $50 \mathrm{~m}$ of shore. Whales foraging offshore often swam in a zigzag pattern rather than in a straight line along a channel. 
Table 3. Orcinus orca. Monthly distribution (for 1974 to 2005) of sampled feeding events where age/sex class of whale making kill was determined; $\mathrm{n}=274$ kills

\begin{tabular}{|lcrrr|}
\hline \multirow{2}{*}{ Month } & \multicolumn{3}{c}{ Age/sex class } & \multirow{2}{*}{ Total } \\
\cline { 2 - 4 } & Adult male & Adult female & Juvenile & \\
\hline May & 8 & 5 & 1 & 14 \\
Jun & 7 & 2 & 1 & 10 \\
Jul & 16 & 26 & 25 & 67 \\
Aug & 19 & 71 & 31 & 121 \\
Sep & 13 & 3 & 6 & 22 \\
Oct & 14 & 15 & 11 & 40 \\
Total & 77 & 122 & 75 & 274 \\
\hline
\end{tabular}

Signs of prey pursuit and capture were at times very conspicuous. When an appropriate prey item was detected, an individual would break suddenly into a high-speed chase that continued for 10 to $30 \mathrm{~s}$, or (rarely) up to $3 \mathrm{~min}$. Chases were directional and nondirectional, the latter accompanied by fast turns and rolls at the surface. Chases often took place along steep shorelines, with whales swimming at high speed within a few metres of the rocks. Although vigorous chases were obvious indicators of predation, more often signs of feeding were quite subtle, and close attention to several behavioural cues was necessary in order to detect them. For example, a change in the otherwise consistent swimming speed and direction of foraging whales often indicated that a pursuit was underway. An unusually long 5 to 7 min dive following an extended series of regular, 2 to 3 min dives was also a good indication of prey pursuit and possible capture.

Whale interactions during feeding events indicated that the majority of prey items were shared by 2 or more individuals. Typically, a whale that made a kill was joined by others, and the group would swim together for 2 to 3 surfacings before splitting up once again. Individuals converged on the successful whale from as far as $400 \mathrm{~m}$, although more often joining whales were within 100 to $200 \mathrm{~m}$ when the kill took place. On other occasions, several whales were involved in the pursuit and would work cooperatively to take prey that had sought refuge in crevices along rocky shorelines or in kelp beds. After making the kill, members of the group joined at the surface and swam together for several surfacings. Inspection of the site at which whales joined in such situations invariably revealed fish scales or pieces of tissue in the water. Often, as the whales swam together after joining, a trail of prey fragments was left in the water, indicating that the prey item was being torn up along the way.

Close observations of prey handling and consumption provided strong evidence that sharing was taking place in such circumstances, and that intentional provisioning of other whales was also frequently involved.
Table 4. Orcinus orca. Frequency of prey sharing in feeding events by resident killer whales where age and/or sex class of individuals making kills could be determined. Juvenile whales were $<14$ yr old

\begin{tabular}{|lcccc|}
\hline \multirow{2}{*}{ Sharing } & \multicolumn{3}{c}{ Age/sex class } & \multirow{2}{*}{ Total } \\
\cline { 2 - 4 } & Adult male & Adult female & Juvenile & \\
\hline Yes & 9 & 97 & 36 & 142 \\
No & 44 & 4 & 9 & 57 \\
Total & 53 & 101 & 45 & 199 \\
\hline
\end{tabular}

On numerous occasions, members of a subgroup milled at the surface while one of the group was underwater on a long dive. Upon surfacing with prey, the whale was seen to carry the fish in the direction of the milling individuals. Scales and/or tissue were found where the whales joined. On other occasions, a whale was observed to surface with prey and carry it for 3 to 5 shallow dives and surfacings while another whale swam quickly in its direction. Although small numbers of scales were often seen in the water in the trail of the whale carrying the fish, much larger numbers of scales and pieces of tissue were observed at the site of joining, indicating that prey consumption was delayed until the whales were together.

Observations during 235 feeding events provided sufficient evidence to judge with reasonable confidence whether or not sharing took place. In 57 of these feeding events $(24 \%)$ there was no indication of any sharing. In the other 178 cases $(76 \%)$, sharing was either clearly evident or strongly suspected. Between 2 and 6 whales (including the individual making the kill) were involved in shared feeding events, though it was generally not possible to determine how many individuals actually took part in prey consumption. Whales involved in shared feeding events typically belonged to the same matriline. The frequency of sharing by members of different age and sex classes of whales differed significantly $\left(\chi^{2}=30.8\right.$, df $=2$, $\mathrm{p}<0.001$; Table 4), with adult males sharing significantly fewer of their kills $(17 \%)$ than expected compared to adult females (96\%) and juveniles $(80 \%)$, (these were not distinguished by sex).

\section{Prey species and age composition}

All 529 feeding events involved fishes, at least $96 \%$ of which were salmonids (Table 2). We could not identify 10 samples $(2.5 \%)$ to species, and some of these may also have been salmonids. The only non-salmonids identified were 3 Pacific herring Clupea pallasi, 1 sablefish Anoplopoma fimbria, 1 yelloweye rockfish Sebastes ruberrimus, 1 quillback rockfish $S$. maliger, and 1 Pacific halibut Hippocampus stenolepis. 
Table 5. Orcinus orca. Ages of 344 salmonids killed by resident killer whales. Ages given in European system, whereby years in freshwater after hatching and years in salt water are identified and separated by decimal point. Age classes used elsewhere in this paper were obtained by summing the 2 European age values and adding 1 (e.g. 1.2 age converts to a 4 th yr fish). Specific names of prey in Table 2

\begin{tabular}{|c|c|c|c|c|c|c|c|c|c|c|c|c|c|}
\hline \multirow{2}{*}{ Species } & \multirow[t]{2}{*}{$\mathrm{n}$} & \multicolumn{12}{|c|}{ - Age class } \\
\hline & & 0.1 & 0.2 & 0.3 & 0.4 & 0.5 & 1.1 & 1.2 & 1.3 & 1.4 & 1.5 & 2.1 & 2.2 \\
\hline Chinook & 236 & 1 & 25 & 94 & 49 & 2 & 3 & 16 & 34 & 10 & 1 & & 1 \\
\hline Coho & 9 & & & & & & 8 & & & & & 1 & \\
\hline Chum & 87 & & & 57 & 27 & 3 & & & & & & & \\
\hline Pink & 12 & 12 & & & & & & & & & & & \\
\hline
\end{tabular}

salmonid kills by adult males was significantly greater than in kills by adult females and juveniles $\left(\chi^{2}=10.4\right.$, df $=1$, $\mathrm{p}<0.01)$. This difference may be due to a seasonal bias in sampling of kills by different sexes. A greater proportion of kills by males $(35 \%$ of total samples from males; Table 3) than by females (15\% of total, Table 3 ) were sampled during September and October, when chum salmon was the predominant prey species (Table 7). All 11 pink salmon kills by identified whales were by juveniles. In fact, 6 of the 11 pink

Of the 7 species of Pacific salmon (Oncorhynchus spp.) found in the study area, 6 were represented in feeding samples (the exception was the cutthroat trout O. clarki). Species identity was determined for 432 salmonids, 20 by DNA analysis and the remainder by scale analysis. The frequency of occurrence of these species in whale kills is shown by region in Table 2 . Chinook salmon was by far the predominant salmonid observed, representing $71.5 \%$ of salmonid kills identified to species. The second most important salmonid was chum, at $22.7 \%$ of samples. Coho, pink, sockeye and steelhead together represented less than $6 \%$ of the salmonids identified. Ages were determined for 344 salmonid samples (Table 5).

Chinook was the principal species taken by resident killer whales in all regions of the coast (Table 2). It was the most common species in feeding samples from both northern and southern communities, as well as from each of the resident clans (Table 6). Chinook represented the majority of salmonid samples collected from resident killer whales during May to August (Table 7). However, chum salmon was the predominant species identified from feeding events in September to October. Pink salmon occurred in small numbers in July to September samples, as did coho salmon during July to October. Southern residents were responsible for the single sockeye salmon sample, collected in July, and the 2 steelhead samples, collected in November and December.

\section{Prey selection as a function of whale age/sex class}

Adult male, adult female and juvenile ( $<14$ yr old) resident killer whales all preyed on chinook salmon more than on any other species (Table 8). Chum and coho salmon were also taken by each sex and age category, although the proportion of chum in salmon kills were made during a single $1.5 \mathrm{~h}$ long feeding session by a 1 yr old calf. Because pink salmon are the smallest of the Pacific salmonids (Quinn 2005), we examined the age distribution of chinook salmon kills to determine if younger (and thus smaller) salmon were taken more frequently by young whales than by adults. The mass of chinook salmon increases dramatically with increasing age, from a mean of $1.1 \mathrm{~kg}$ in $2 \mathrm{yr}$ old fish to over $13 \mathrm{~kg}$ in 5 to $6 \mathrm{yr}$ old fish (Table 9).

Table 6. Orcinus orca. Salmonid species sampled from feeding events by members of different resident clans. Clans A, G and $\mathrm{R}$ form the northern community, Clan $\mathrm{J}$ is the southern community. Sample size ( $\mathrm{n}=423$ kills) differs from Tables $2 \&$ 7 because not all kills could be positively attributed to specific individuals or their clans. Specific names of prey in Table 2

\begin{tabular}{|lrrrrr|}
\hline \multirow{2}{*}{ Species } & \multicolumn{4}{c}{ Clan } & \multicolumn{2}{c}{ Total } \\
\cline { 2 - 4 } & $\mathrm{A}$ & $\mathrm{G}$ & $\mathrm{R}$ & $\mathrm{J}$ & \\
\hline Chinook & 178 & 70 & 19 & 39 & 306 \\
Chum & 64 & 24 & 4 & 2 & 94 \\
Coho & 7 & 0 & 0 & 2 & 9 \\
Pink & 9 & 2 & 0 & 0 & 11 \\
Sockeye & 0 & 0 & 0 & 1 & 1 \\
Steelhead & 0 & 0 & 0 & 2 & 2 \\
Total & 258 & 96 & 23 & 46 & 423 \\
\hline
\end{tabular}

Table 7. Orcinus orca. Salmonid species sampled from resident killer whale feeding events by month; $\mathrm{n}=432$ kills. Specific names of prey in Table 2

\begin{tabular}{|c|c|c|c|c|c|c|c|}
\hline \multirow{2}{*}{ Month } & \multirow[b]{2}{*}{ Chinook } & \multirow[b]{2}{*}{ Chum } & \multicolumn{2}{|c|}{ Species } & \multirow{2}{*}{\multicolumn{2}{|c|}{ Sockeye Steelhead }} & \multirow{2}{*}{ Total } \\
\hline & & & Coho & Pink & & & \\
\hline May & 22 & 0 & 0 & 0 & 0 & 0 & 22 \\
\hline Jun & 34 & 12 & 0 & 0 & 0 & 0 & 46 \\
\hline Jul & 94 & 13 & 1 & 0 & 1 & 0 & 109 \\
\hline Aug & 139 & 3 & 4 & 11 & 0 & 0 & 157 \\
\hline Sep & 11 & 22 & 1 & 2 & 0 & 0 & 36 \\
\hline Oct & 8 & 48 & 3 & 0 & 0 & 0 & 59 \\
\hline Nov & 1 & 0 & 0 & 0 & 0 & 1 & 2 \\
\hline Dec & 0 & 0 & 0 & 0 & 0 & 1 & 1 \\
\hline Total & 309 & 98 & 9 & 13 & 1 & 2 & 432 \\
\hline
\end{tabular}


Table 8. Orcinus orca. Salmonid species sampled from feeding events as a function of age and sex class of resident whales; $n=274$ kills. Specific names of prey in Table 2

\begin{tabular}{|lcrrr}
\hline \multirow{2}{*}{ Species } & \multicolumn{3}{c}{ Age/sex class } & \multirow{2}{*}{ Total } \\
\cline { 2 - 4 } & Adult male & Adult female & Juvenile & \\
\hline Chinook & 47 & 104 & 40 & 191 \\
Chum & 26 & 16 & 23 & 65 \\
Coho & 4 & 2 & 1 & 7 \\
Pink & 0 & 0 & 11 & 11 \\
Total & 77 & 122 & 75 & 274 \\
\hline
\end{tabular}

Table 9. Oncorhynchus tshawytscha. Mean fork lengths and mass $( \pm \mathrm{SE})$ of chinook salmon at different ages. Data from seine caught fish in Mark Recovery Program of Fisheries and Oceans Canada (Kuhn 1988)

\begin{tabular}{|lccr|}
\hline Age (yr) & Length (mm) & Mean mass $(\mathrm{kg})$ & \multicolumn{1}{c|}{$\mathrm{n}$} \\
\hline 2 & $425 \pm 1.19$ & $1.1 \pm 0.01$ & 3072 \\
3 & $581 \pm 2.14$ & $3.1 \pm 0.04$ & 3206 \\
4 & $808 \pm 3.43$ & $8.5 \pm 0.11$ & 917 \\
5 & $939 \pm 4.21$ & $13.3 \pm 0.20$ & 426 \\
6 & $961 \pm 15.0$ & $13.7 \pm 0.72$ & 37 \\
\hline
\end{tabular}

Although the smallest chinook ( 2 and 3 yr olds) were taken more often by juvenile than by adult whales (Fig. 2), the overall trend was not significant ( $U$-test $=$ $1688, \mathrm{p}=0.11)$. There was also no significant difference $(U$-test $=1377.5, \mathrm{p}=0.13)$ between the mean age of chinook taken by adult males $(4.50 \mathrm{yr} \pm 0.13 \mathrm{SE}, \mathrm{n}=$ 38 ) and by adult females (4.26 yr $\pm 0.08 \mathrm{SE}, \mathrm{n}=86)$.

\section{Prey species and sizes in shared and non-shared kills}

Of the 6 salmonid species taken by resident killer whales, 4 were identified from both shared and nonshared feeding events (Table 10). The great majority (84\%) of chinook salmon tended to be shared, while a significantly lower proportion of chum salmon were shared $\left(55 \% ; \chi^{2}=4.47\right.$, df $\left.=1, \mathrm{p}<0.05\right)$. Although chinook are often larger than chum salmon (Healey 1986), larger size appears not to be the reason for the greater incidence of sharing of chinook. Chum salmon formed a higher proportion of the prey samples from adult males than from adult females, and because males shared prey less frequently than females, the proportion of chum that were not shared may as a result be higher than for other species. Both coho and pink salmon, which tend to be smaller than chum (Healey 1986), were noted in both shared and non-shared feeding events. Also, the frequency of sharing of chinook salmon did not differ with the age, and hence the size, of the fish (Fig. 3). The mean age of chinook taken in shared kills was $4.28 \mathrm{yr}( \pm 0.07 \mathrm{SE}, \mathrm{n}=117$ kills $)$, which was not significantly different from the mean age of $4.27 \mathrm{yr}( \pm 0.16 \mathrm{SE}, \mathrm{n}=22$ kills $)$ of chinook taken in nonshared kills $(U$-test $=1260, \mathrm{p}=0.87)$.

\section{Prey selection versus availability}

To assess the extent to which foraging resident killer whales select for particular species or sizes of salmonids, the species and age composition of kills sampled off NE Vancouver Island was compared to salmonid availability. The relative abundance of salmonids was determined from catch statistics resulting from Fisheries and Oceans Canada seine test fisheries (Data available from www-ops2.pac.dfo-mpo.gc.ca/ xnet/content/salmon/testfish/default.htm), which were undertaken concurrently with and in close proximity to our sampling of killer whale feeding events in the western Johnstone Strait area, off NE Vancouver Island (see Fig. 1). These data provide a reliable index of the relative availability of different salmonid species to the whales foraging in that area during particular periods of the season. Fig. 4 illustrates the species composition of salmonids caught in test fisheries and by resident killer whales during 3 periods in July to October 2004. From 15 July to 15 August, the test catches

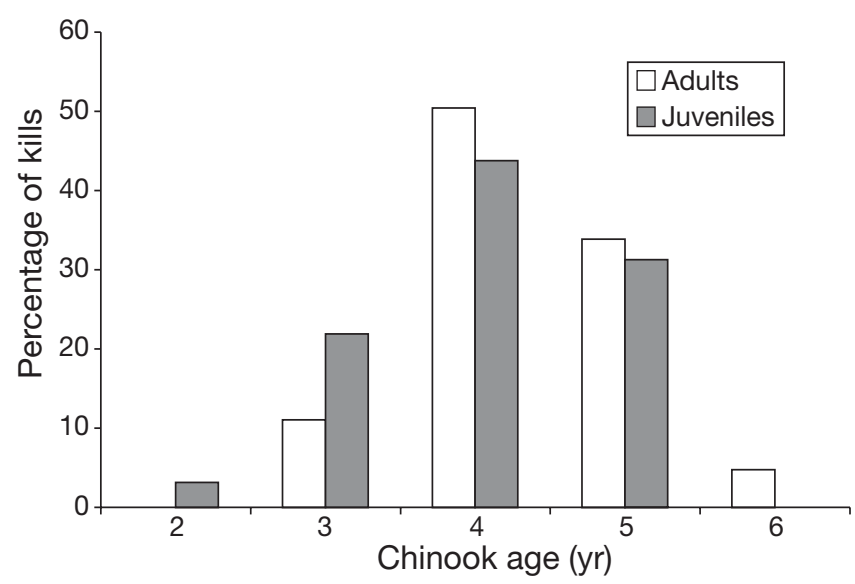

Fig. 2. Oncorhynchus tshawytscha. Age distribution of chinook salmon taken by adult ( $\mathrm{n}=127$ kills) and juvenile $(\mathrm{n}=32$ kills) resident killer whales Orcinus orca

Table 10. Orcinus orca. Frequency of prey sharing by resident killer whales in feeding events where prey was identified to species. $n=229$ kills. Specific names of prey in Table 2

\begin{tabular}{|lrrrrr|}
\hline \multirow{2}{*}{ Sharing } & \multicolumn{4}{c}{ Prey species } & \multirow{2}{*}{ Total } \\
\cline { 2 - 4 } & Chinook & Chum & Coho & Pink & \\
\hline Yes & 141 & 29 & 3 & 1 & 174 \\
No & 27 & 24 & 3 & 1 & 55 \\
Total & 168 & 53 & 6 & 2 & 229 \\
\hline
\end{tabular}




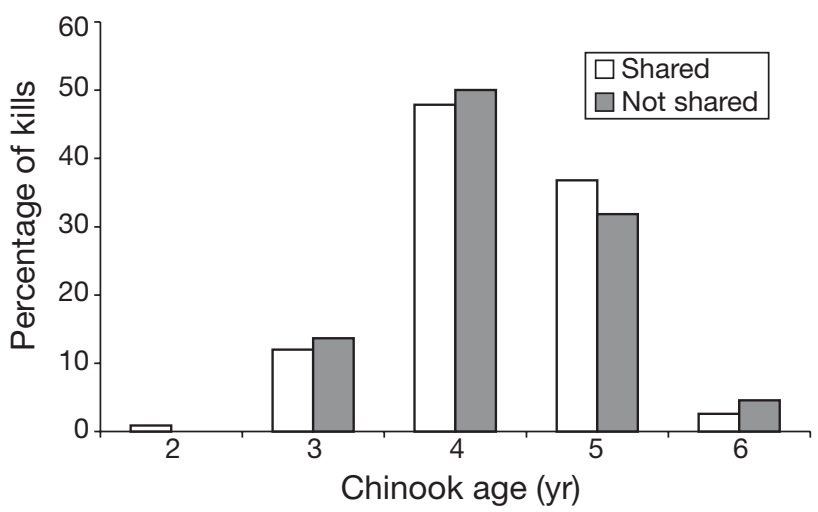

Fig. 3. Oncorhynchus tshawytscha. Age distribution of chinook salmon taken in shared ( $\mathrm{n}=117$ kills) and non-shared ( $\mathrm{n}=22$ kills) feeding events by Orcinus orca

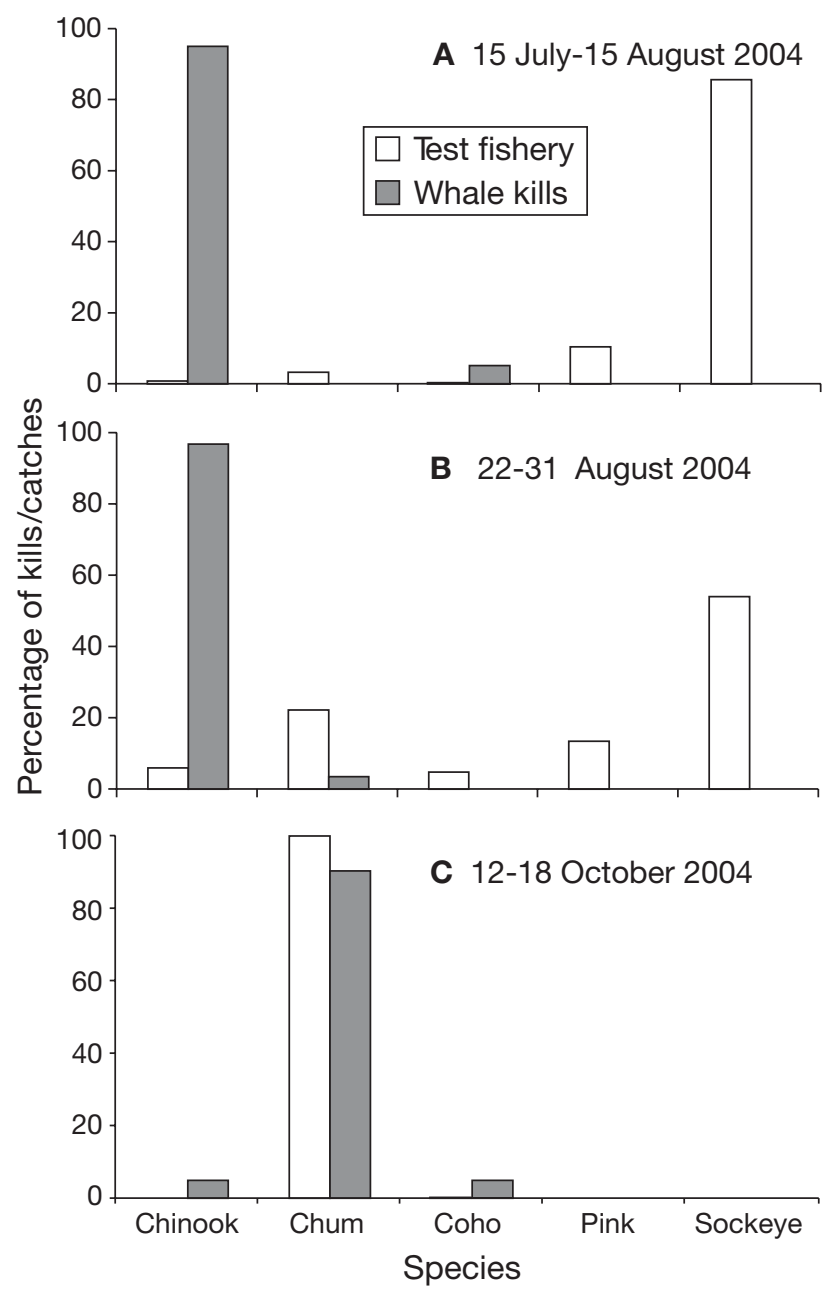

Fig. 4. Species composition of salmonids caught in seine test fisheries (open bars) and by resident killer whales (shaded bars) in western Johnstone Strait area, NE Vancouver Island from (A) 15 July to 15 August, (B) 22 to 31 August and (C) 12 to 18 October 2004. Samples sizes were (A) 69847 (test fishery) and 59 (whale kills), (B) 1548 (test fishery) and 30 (whale kills), and (C) 57435 (test fishery) and 41 (whale kills). Specific names of prey in Table 2 were dominated by migrating sockeye and pink salmon, which together comprised over $90 \%$ of salmon sampled. During this period, 59 salmonid kills by resident killer whales in the area were documented, $95 \%$ of which were chinook and $5 \%$ coho (Fig. 4A). These 2 species each represented less than $1 \%$ of the available salmonids in the area. During 22 to 31 August 2004, the abundance of chinook increased to approximately $6 \%$ of the available salmonids, and represented $97 \%$ of kills during this period (Fig. 4B). A substantial change in the relative abundance of both salmonids and kills by killer whales took place between 12 and 18 October 2004 (Fig. 4C). Autumn-migrating chum salmon comprised $97 \%$ of the test fishery catch during this period, and chum was the predominant salmonid taken by feeding killer whales (90\% of kills). Chinook still represented $5 \%$ of kills during this period despite being extremely scarce in test catches (1 chinook in 57435 salmonids sampled).

To evaluate whether resident killer whales preyed equally on all sizes of their preferred prey species, the age distribution of chinook salmon taken by whales was compared to the age distribution of chinook available to them for waters off NE Vancouver Island in 2000 to 2004. The relative abundance of chinook age classes was determined from estimates developed by the Pacific Salmon Commission Joint Chinook Technical Committee $\mathbf{1}$. Although killer whales took all $5 \mathrm{yr}$ classes available to them (Fig. 5), the frequency distributions were significantly different, with killer whales taking fewer young chinook and more older chinook than expected based on the proportions of those ages available. The mean age of chinook taken by whales was $4.20 \mathrm{yr}( \pm 0.06 \mathrm{SE}, \mathrm{n}=124)$, significantly older than the mean of $3.52 \mathrm{yr}( \pm 0.03 \mathrm{SE}, \mathrm{n}=976,212)$ for available chinook ( $U$-test $=33057, \mathrm{p}<0.001)$.

\section{DISCUSSION}

Assessing the selectivity of a predator requires information on both the predator's diet and the relative availability of its various prey types. Although such information is often readily available for terrestrial predators (e.g. Scheel 1993, Karanth \& Sunquist 1995), it can be very difficult to obtain for fish-eating marine mammals. The diet of aquatic predators must usually be determined by indirect means, such as from stomach content, faecal, or fatty acid analyses, and the

\footnotetext{
1Descriptions of the PSC chinook model and calibration procedures are provided in Pacific Salmon Commission Joint Chinook Technical Committee Report TCChinook (97)-2, 1997, and Report TCChinook (04)-2. Available at www.psc.org/ publications_tech_techcommitteereport.htm\#TCCHINOOK
} 


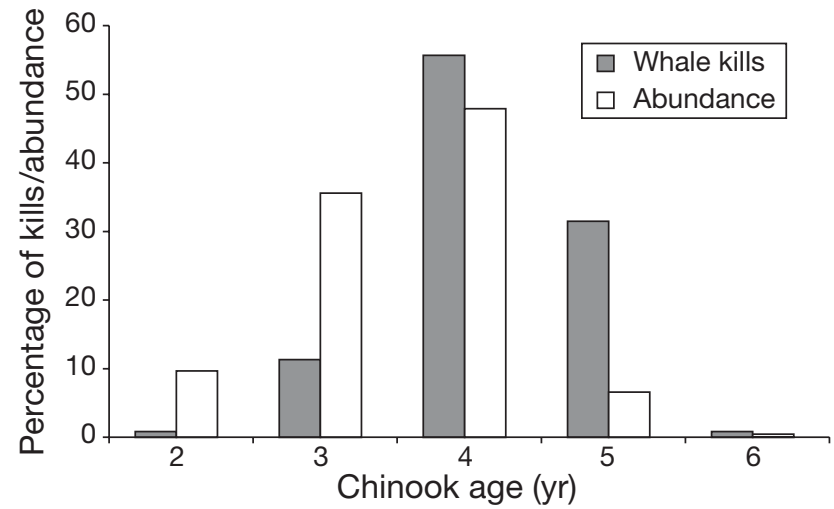

Fig. 5. Oncorhynchus tshawytscha. Age distribution of 124 chinook salmon preyed upon by resident killer whales Orcinus orca in Pacific Fisheries Management Area 12 (NE Vancouver Island) from 2000 to 2004, compared to relative abundance of chinook age classes estimated to have been available to the whales in the area during same period. Age distribution of available chinook was derived from cumulative abundance estimates of 976212 fish over the $5 \mathrm{yr}$ period (see Footnote 1 in 'Results')

abundance of prey species is seldom known unless those species are assessed for commercial fisheries (Bowen and Siniff 1999). Studies on foraging in pinnipeds have revealed prey selection based on size, energy density or profitability (Tollit et al. 1997, Lawson et al. 1998, Bowen et al. 2002), but no comparable analyses have until now been undertaken for a cetacean. Our study is the first to analyse a large number of feeding events involving a variety of prey species positively identified either by direct observation or from prey fragments, and to compare predation rates with availability of prey species and age classes determined from concurrent abundance assessments. Our findings indicate that, for a significant part of the year, resident killer whales fed on certain prey species at rates far out of proportion to their relative availability compared to other alternative prey. This strong selectivity is likely to have important influences on the whales' foraging tactics and seasonal movements, as well as on their social structure and behaviour.

\section{Prey fragments as indicators of diet}

The reliability of our data on prey selection by resident killer whales is dependent on all prey species having a similar-ideally equal — probability of being sampled from kill sites. Concerns about potential biases of the prey fragment sampling technique that have been raised include (1) the possibility that large fishes, such as chinook, are more subject to being broken up prior to consumption and are thus more likely to shed scales or tissue than smaller fishes, and (2) the possibility that whales foraging at depth are less likely to bring prey to the surface prior to consumption than prey captured in the upper portion of the water column (Ford et al. 1998, Baird 2000, Baird et al. 2005). Our findings reported here suggest that neither of these potential biases is significant enough to alter the patterns of prey selection we describe, particularly with respect to salmonid prey.

Most feeding events, especially those by female and juvenile whales, involved the transport of the prey item to the surface, where it was broken up for sharing or provisioning. Chinook, chum, coho and pink salmon, which differ widely in average size (Healey 1986, Groot \& Margolis 1991), were all shared, suggesting that salmonids are shared regardless of prey size. Also, the age distribution of chinook salmon taken in shared and non-shared feeding events did not differ significantly, providing further evidence that sharing is independent of prey size. Thus, we conclude that salmonid prey is typically brought to the surface and torn apart for social feeding, rather than to facilitate the consumption of large prey items. Adult male killer whales, which shared the minority of their prey, brought a range of salmonid species and sizes to the surface to be consumed alone. Although it is not clear why adult males do this, we suspect that consumption of prey at the surface is routine in these whales.

Although sharing of salmonid prey was noted earlier in our opportunistic studies of resident killer whale predation (Ford et al. 1998), the extent of this behaviour was not apparent until close focal individual and subgroup observations were undertaken during feeding sessions. Signs of prey capture, handling and consumption are subtle and easily overlooked, and consistent detection of these cues requires considerable experience. Given this difficulty, it is not surprising that previous descriptions of the foraging behaviour of resident killer whales, which were generally based on less field effort and/or on opportunistically-collected samples, have not reported food sharing (Jacobsen 1986, Heimlich-Boran 1988, Felleman et al. 1991, Hoelzel 1993, Nichol \& Shackleton 1996, Saulitis et al. 2000).

There is no evidence that proximity to the surface differentially affected the likelihood of salmonid prey species being represented in feeding samples. Fish tracking studies off NE Vancouver Island, where the majority of our salmonid prey samples were collected, revealed that chinook travelled at mean depths of 25 to $64 \mathrm{~m}$ during the day compared to $14.9 \mathrm{~m}$ in sockeye salmon (Candy \& Quinn 1999). Despite being deeper and much less abundant than sockeye in this area during July and August (Fig. 5), chinook salmon was by far the predominant species observed in feeding events, and no sockeye salmon were found in prey samples. For these same reasons, prey fragment collection from feeding events should reveal kills of demersal, nonsalmonid fish species as well as salmonids, and we be- 
lieve that the scarcity of non-salmonids in our samples is a true reflection of their minor role in the diet of resident killer whales, at least during the seasons covered by our observations. For example, lingcod Ophiodon elongatus, found in stomach remains of a stranded resident whale (Ford et al. 1998), reach similar sizes to chinook salmon and are most abundant at depths of 10 to $100 \mathrm{~m}$, which overlap the preferred depths of chinook salmon (Cass et al. 1990, Candy and Quinn 1999). Lingcod have extremely small scales that are unlikely to be shed or recovered, but fish species identification is not reliant on scales alone. Tissue samples, from which species identity can be readily determined using molecular techniques, were collected from almost half of the feeding events sampled during 2003 to 2005. Of 21 prey items identified solely by DNA analysis of tissue fragments, only 1, a sablefish, was a non-salmonid. We thus conclude that any negative bias in representation of bottomfishes in our samples is unlikely to be significant. Studies of diving behaviour in southern resident killer whales found most activity to be concentrated in the upper portion of the water column (Baird et al. 2005), which would be expected of a predator focused on salmonid rather than demersal prey.

\section{Prey selection}

During the months of May to October, the main period of our field studies, salmonids are clearly the preferred prey type of resident killer whales, representing over $96 \%$ of identified prey. The only non-salmonids found were a Pacific halibut, 2 rockfishes, a sablefish and 3 herring. Although the halibut and sablefish were eaten, both rockfish species were abandoned by the whales after being partially consumed. We suspect that rockfishes may be an undesirable prey type due to their prominent dorsal spines, as this part of the fishes' body was discarded. No rockfish remains have been found in stomach contents of stranded resident killer whales (Ford et al. 1998). It seems unlikely that the herring were targeted prey items, since herring scales were collected only during feeding sessions involving chinook prey. As chinook feed extensively on herring (Healey 1991), it is likely that herring scales were released when whales killed and broke chinook apart or were left in the water after chinook predation on herring.

Chinook and chum salmon together represented $94 \%$ of salmonids identified from kills by resident whales. Chinook is the predominant species taken during May to August. This would be expected for May and June, since other salmonids are uncommon in nearshore waters during these months (Groot \& Margolis 1991, Quinn 2005). However, chinook remains the predominant prey species in July and August, when migrating sockeye and pink salmon form the overwhelming majority of salmonids available to the whales (our Fig. 4; Groot \& Margolis 1991, Nichol \& Shackelton 1996, Wydoski \& Whitney 2003, Quinn 2005). With only a single sockeye kill sample collected, it is clear that despite its abundance during the summer migratory period, this species is rare in the diet of resident killer whales. Pink salmon were also very uncommon in our samples, and the species does not appear to be a significant prey item. Coho salmon are relatively uncommon throughout the region (Groot and Margolis 1991, Wydoski and Whitney 2003, Riddell 2004, Quinn 2005), and were consistently represented in small numbers in killer whale feeding events. Early summer runs of chum salmon occur during June and July, particularly on the northern coast of British Columbia (Riddell 2004), and this species represented a significant component of the killer whale diet in this period and region. During September and October, the diet of northern resident killer whales shifts to predominantly chum salmon, although chinook are also taken frequently. This period coincides with the autumn migration of chum salmon through the area, which starts in mid-September, peaks in mid-October, and is over by late October (Ryall et al. 1999).

Comparisons of prey selection by resident killer whale communities and clans revealed few differences. Northern and southern resident communities both fed predominantly on chinook. The greater proportion of chum in the samples of northern resident $A$ and $\mathrm{G}$ clans probably resulted from their presence off NE Vancouver Island during September and October 2003 and 2004, when intensive sampling was undertaken. Little sampling of feeding events by $\mathrm{R}$ and $\mathrm{J}$ clans during autumn has yet been undertaken. It appears likely that southern resident whales also target chum salmon in addition to chinook in the autumn, as their movement into waters of Puget Sound in late October and November coincides with migratory aggregations of these species (Osborne 1999). The single sockeye and 2 steelhead salmon kills were observed only in southern residents, but this might be due to chance, as a result of such small sample sizes. Different age and sex classes of resident killer whales did show some differences in salmonid prey composition. Kills of pink salmon were made primarily by juvenile whales, and such predation of these small salmonids may represent a form of play or practice (Jacobsen 1986, Ford et al. 1998). Chinook, chum and coho were taken by both adults and juveniles and by both sexes, but a higher proportion of chum salmon kills were recorded for adult males than for adult females. As noted previously, this difference may be due to a bias towards disproportionately greater sampling of kills by males in September and October, 
when chum salmon was the predominant prey species. Bain (1989) suggested that the larger body size of males may allow them to dive more deeply and take larger prey than females. Baird et al. (2005) observed male southern residents to dive deeper more frequently than adult females. However, we observed no difference in the mean ages, and thus general sizes, of chinook taken by the 2 sexes.

Important factors influencing prey selection by predators include size, energy density, availability, and catchability of prey (Stephens \& Krebs 1986, Scheel 1993, Lawson et al. 1998, Bowen et al. 2002). Resident killer whales probably prefer chinook and chum salmon over other salmonids primarily because of their large size. Chinook salmon are the largest of the salmonids, and can attain masses of $>25 \mathrm{~kg}$ (Healey 1991, Quinn 2005). Most chinook taken by killer whales were 4 to 6 yr old, representing mean masses of $>8 \mathrm{~kg}$. Chum salmon are smaller, having mean masses of 5.0 to $7.5 \mathrm{~kg}$ (Ricker 1980, Salo 1991). Both species are significantly larger than coho (mean mass $=2.95 \mathrm{~kg}$; Sandercock 1991), sockeye (mean mass $=2.73 \mathrm{~kg}$; Burgner 1991) and pink salmon (mean mass $=1.7$ to $2.4 \mathrm{~kg}$; Heard 1991). Northern resident killer whales foraging off NE Vancouver Island selected chinook that were older on average than would be predicted from the age distribution of available chinook, indicating a preference for larger-sized fish of this species. It is interesting, however, that the whales also took significant numbers of $3 \mathrm{yr}$ old chinook, which are similar in size to the far more abundant but rarely selected sockeye and pink salmon. It may be that the relatively high lipid content of chinook compared to other salmonids (Stansby 1976, Healey 1986, Winship \& Trites 2003) is another factor in the whales' preference for this species. However, chum salmon is a significant prey species, despite having lower average lipid content than other salmonids (Stansby 1976), suggesting that size may be a more important influence than lipid content in determining salmonid preferences.

Evidence from other regions also suggests that both prey size and lipid content may influence prey choice by fish-eating killer whales. Saulitis et al. (2000) found that resident killer whales in Prince William Sound, Alaska, appeared to prey selectively on coho salmon, which are larger and have higher lipid content than the far more abundant pink salmon that were available to the whales during their study. Chinook are extremely rare in Prince William Sound during July and August, when prey sampling was conducted by Saulitis et al. (2000), which probably explains why few of this species were found in their samples. These whales prey extensively on chinook at other times and in other areas where this prey species is present (C. Matkin, North Gulf Oceanic Society, Homer, Alaska, pers. comm.). Killer whales in Prince William Sound and in the Bering Sea are also known to remove and eat fishes from longline fishing gear, but they do so selectively, according to energy value and size. Pacific halibut, sablefish and Greenland turbot Reinhardtius hippoglossoides are among the favoured species, and the whales take the largest individuals of these species from fishing lines while ignoring other species such as Pacific cod Gadus macrocephalus, walleye pollock Theragra chalcogramma, and rockfish Sebastes spp. (Matkin \& Saulitis 1994, Yano \& Dahlheim 1995). Favoured species have higher average lipid content and energy densities than species that are shunned (Stansby 1976, Winship \& Trites 2003).

Although size and lipid content may be important factors in prey selection by resident killer whales, it is not clear why so few sockeye and pink salmon are taken given their considerable seasonal abundance. During the peak of their migration through whale foraging areas, from mid-July to mid-September, sockeye and pink salmon combined outnumber chinook by as many as 500 to 1 (DFO seine test fisheries data, see 'Results'). We believe that it is a combination of the chinook salmon's large size, high lipid content, and yearround availability that makes them the salmonid of choice for resident whales in all seasons, even when alternative species are available in greater abundance during brief migratory pulses.

Unlike most salmonids, chinook are available to resident killer whales in nearshore waters of the region throughout the year. The 'ocean-type' chinook ranges over continental shelf waters throughout the marine portion of its life cycle (Healey 1991). The timing of migration to spawning rivers is highly variable in chinook, with different populations of chinook entering freshwater from mid-spring through autumn (Healey 1991). Migrating chinook also tend to travel through coastal waters at slow rates of speed compared to other salmonids (Candy \& Quinn 1999). Sockeye, chum and pink salmon, on the other hand, have oceanic distributions most of their lives and only transit coastal regions briefly while en route to spawning rivers (Groot \& Margolis 1991). The oceanic range of these salmonids is vast (Groot \& Margolis 1991), with fishes distributed widely at densities that are probably too low for whales to effectively utilise. Although resident killer whales range extensively along the coast, there is no evidence that they undertake long distance movements to offshore areas (Ford et al. 2000, Wiles 2004). Sockeye, chum, and pink salmon, the 3 most abundant salmonids in the North Pacific, are thus only available for predation by resident killer whales for a small portion of the year compared to chinook salmon.

Killer whale populations tend to have specialised foraging tactics to hunt their preferred prey (Lopez \& 
Lopez 1985, Guinet 1992, Barrett-Lennard et al. 1996, Baird 2000, Saulitis et al. 2000, Pitman \& Ensor 2003), and this is likely to be the case for resident killer whales also. Resident killer whales may be particularly skilled at finding and capturing chinook, which tend to travel more individually, at greater depths and closer to shore than smaller, schooling salmonids (Groot \& Margolis 1991, Candy \& Quinn 1999). The echolocation signals of resident killer whales are well suited for the detection of echoes from individual chinook at ranges of $100 \mathrm{~m}$ or more (Au et al. 2004). Efficient predation of smaller, schooling salmonids such as pink and sockeye salmon would probably require specialised tactics such as the 'carousel' technique used by killer whales to feed on herring in northern Norway (Similä \& Ugarte 1993). Such coordinated foraging behaviour has not been observed in resident killer whales (Heimlich-Boran 1988, Ford 1989). It is noteworthy that resident killer whales do not target the large seasonal concentrations of spawning herring that occur in coastal waters throughout their range.

The known distribution patterns of resident killer whales are consistent with what would be expected of a predator focused on chinook salmon. From May to early July, northern residents are found mostly along the coasts of the northern mainland of British Columbia and the Queen Charlotte Islands, where they congregate in areas of high chinook density and feed primarily on this species (Ford et al. 2000, authors' unpubl. data). This period coincides with the earliest of chinook runs in the region (Riddell 2004). Early-summer-run chum salmon are also found there during this time, although they are preyed upon to a lesser extent than chinook. By mid-July, the whales begin to occur regularly off NE Vancouver Island, concurrently with an increase in chinook abundance in the area and the arrival of migrating sockeye and pink salmon. From mid-July to early September, when sockeye and pink are transiting these waters, chinook salmon are also available at relatively high densities. Although the absolute abundance of chinook is far lower than that of these smaller species, there are probably sufficient numbers available to meet the needs of resident whales without their having to switch to pink or sockeye prey. By October, autumn-migrating chum salmon become the predominant salmonid available and the principle prey of northern residents. Chinook salmon appear to still be taken preferentially during this period, since this species occurred more often in prey samples than would be predicted from its low relative abundance. The movements of southern residents to foraging areas off southern Vancouver Island during June to September also coincide with increased availability of chinook salmon, and in October and November with chum salmon (Osborne 1999).
A significant gap in our knowledge of the feeding ecology of resident killer whales is their diet during November to April. Chinook salmon remain available during these months in the inshore summer and autumn concentration areas of resident killer whales, but mostly at low densities (Osborne 1999; B. Riddell, Pacific Biological Station, Nanaimo, pers. comm.). Whales disperse from these areas during winter and spring, but their whereabouts are for the most part unknown (Ford et al. 2000, Wiles 2004). Their prey may shift in winter and early spring to include more non-salmonid fishes, but there is little evidence to determine the extent to which their diet may change. The stomach of a northern resident whale that died in late November off NE Vancouver Island contained remains of chinook salmon and a variety of demersal fish species, including lingcod, sablefish, and greenling (Hexagrammos sp.; Ford et al. 1998). It is probable that the resident killer whales' preference for chinook continues throughout the winter, and that they travel more widely over remote parts of the coast in pursuit of this species. Future studies are needed to locate resident whales during these months, and to determine whether chinook salmon is indeed their prey of choice throughout the year.

Acknowledgements. The prey fragment sampling technique central to this work was originally developed by the late Michael A. Bigg, a pioneer of modern cetacean science. We thank the many research colleagues and volunteers who helped in the collection of data reported here, including $\mathrm{R}$. Abernethy, K. Balcomb, L. Barrett-Lennard, J. Borrowman, L. Dalla Rosa, M. and B. De Roos, J. Ellis, B. Falconer, B. Ford, M. Ford, B. Gisborne, T. Hardy, J. Hildering, M. Janeway, L. Spaven and J. Watson. For analysis of fish scales and tissue remains, we thank S. MacLellan and staff of the Fish Ageing Laboratory, and J. Candy and K. Miller of the Molecular Genetics Laboratory, Pacific Biological Station, Department of Fisheries and Oceans, Nanaimo, British Columbia. Assistance with data preparation was provided by K. Davies and L. Spaven, and L. Nichol and P. Olesiuk helped with data analysis and interpretation. We are also grateful to R. McNicol, B. Riddell and T. Quinn for providing information on chinook abundance and for helpful discussions about salmonid life history and ecology. Earlier drafts of this manuscript benefited from comments provided by D. Bowen, S. Ferguson, J. Lawson, L. Nichol, G. Stenson, R. Stewart, D. Tollit, H. Yurk, J. Watson and 4 anonymous reviewers. This work was supported by Fisheries and Oceans Canada. The British Columbia Wild Killer Whale Adoption Program, Vancouver Aquarium Marine Science Centre, Stubbs Island Whale Watching, Telegraph Cove, and Langara Fishing Adventures, Vancouver, provided valuable logistical support.

\section{LITERATURE CITED}

Altmann J (1974) Observational study of behavior: sampling methods. Behaviour 49:227-265

$\mathrm{Au}$ WWL, Ford JKB, Horne J, Newman Allman K (2004) Echolocation signals of free-ranging killer whales (Orcinus 
orca) and modeling of foraging for chinook salmon (Oncorhynchus tshawytscha). J Acoust Soc Am 115:901-909

Bain DE (1989) An evaluation of evolutionary processes: studies of natural selection, dispersal, and cultural evolution in killer whales (Orcinus orca). $\mathrm{PhD}$ dissertation, University of California, Santa Cruz

Baird RW (2000) The killer whale: foraging specializations and group hunting. In: Mann J, Connor RC, Tyack PL, Whitehead H (eds) Cetacean societies: field studies of dolphins and whales. University of Chicago Press, Chicago, IL, p 127-153

Baird RW, Dill LM (1995) Occurrence and behaviour of transient killer whales: seasonal and pod-specific variability, foraging, and prey handling. Can J Zool 73:1300-1311

Baird RW, Hanson MB, Dill LM (2005) Factors influencing the diving behaviour of fish-eating killer whales: sex differences and diel and interannual variation in diving rates. Can J Zool 83:257-267

Barrett-Lennard LG (2000) Population structure and mating patterns of killer whales, Orcinus orca, as revealed by DNA analysis. PhD dissertation, University of British Columbia, Vancouver

Barrett-Lennard LG, Ford JKB, Heise KA (1996) The mixed blessing of echolocation: differences in sonar use by fish-eating and mammal-eating killer whales. Anim Behav 51:553-565

Bigg MA (1982) An assessment of killer whale (Orcinus orca) stocks off Vancouver Island, British Columbia. Rep Int Whal Comm 32:655-666

Bigg MA, Ellis GM, Ford JKB, Balcomb KC (1987) Killer whales: a study of their identification, genealogy and natural history in British Columbia and Washington State. Phantom Press, Nanaimo

Bigg MA, Olesiuk PF, Ellis GM, Ford JKB, Balcomb KC III (1990) Social organization and genealogy of resident killer whales (Orcinus orca) in the coastal waters of British Columbia and Washington State. Rep Int Whal Comm Spec Issue 12:383-405

Bowen WD (1997) Role of marine mammals in aquatic ecosystems. Mar Ecol Prog Ser 158:267-274

Bowen WD, Siniff DB (1999) Distribution, population biology, and feeding ecology of marine mammals. In: Reynolds JEI, Rommel SA (eds) Biology of marine mammals. Smithsonian Press, Washington, DC, p 423-484

Bowen WD, Tully D, Boness DJ, Bulheier BM, Marshall GJ (2002) Prey-dependent foraging tactics and prey profitability in a marine mammal. Mar Ecol Prog Ser 244:235-245

Burgner RL (1991) Life history of sockeye salmon (Oncorhynchus nerka). In: Groot C, Margolis L (eds) Pacific salmon life histories. UBC Press, Vancouver, p 3-117

Candy JR, Quinn TP (1999) Behaviour of adult chinook salmon (Oncorhynchus tshawytscha) in British Columbia coastal waters determined from ultrasonic telemetry. Can J Zool 77:1161-1169

Cass AJ, Beamish RJ, McFarlane GA (1990) Lingcod (Ophiodon elongatus). Can Spec Publ Fish Aquat Sci 109

DeMaster DP, Trites AW, Clapham PJ, Mizroch SA, Wade PR, Small RJ, Ver Hoef JM (2006) The sequential megafaunal collapse hypothesis: testing with existing data. Prog Oceanogr 68:329-342

Felleman FL, Heimlich-Boran JR, Osborne RW (1991) The feeding ecology of killer whales (Orcinus orca) in the Pacific northwest. In: Pryor K, Norris KS (eds) Dolphin Societies: discoveries and puzzles. University of California Press, Berkeley, p 113-147

Fertl D, Acevedo-Gutierrez A, Darby FL (1996) A report of killer whales (Orcinus orca) feeding on a carcharhinid shark in Costa Rica. Mar Mamm Sci 12:606-611
Ford JKB (1989) Acoustic behaviour of resident killer whales (Orcinus orca) off Vancouver Island, British Columbia. Can J Zool 67:727-745

Ford JKB, Ellis GM (1999) Transients: mammal-hunting killer whales of British Columbia, Washington, and Southeastern Alaska. UBC Press, Vancouver

Ford JKB, Ellis GM, Barrett-Lennard LG, Morton AB, Palm RS, Balcomb KC III (1998) Dietary specialization in two sympatric populations of killer whales (Orcinus orca) in coastal British Columbia and adjacent waters. Can J Zool 76:1456-1471

Ford JKB, Ellis GM, Balcomb KC (2000) Killer whales: the natural history and genealogy of Orcinus orca in the waters of British Columbia and Washington, 2nd edn. UBC Press, Vancouver

Ford JKB, Ellis GM, Matkin DR, Balcomb KC, Briggs D, Morton AB (2005) Killer whale attacks on minke whales: prey capture and antipredator tactics. Mar Mamm Sci 21: $603-618$

Groot C, Margolis L (eds) (1991) Pacific salmon life histories. UBC Press, Vancouver

Guinet C (1990) Sympatrie des deux categories d'orques dans le detroit de Johnstone, Columbie Britannique. Rev Ecol Terre Vie 45:25-34

Guinet C (1992) Comportement de chasse des orques (Orcinus orca) autour des iles Crozet. Can J Zool 70:1656-1667

Guinet C, Bouvier J (1995) Development of intentional stranding hunting techniques in killer whale (Orcinus orca) calves at Crozet Archipelago. Can J Zool 73:27-33

Haley D (ed) (1986) Marine mammals of eastern North Pacific and Arctic waters, 2nd edn. Pacific Search Press, Seattle, WA

Healey MC (1986) Optimum size and age at maturity in Pacific salmon and effects of size-selective fisheries. In: Meerburg DJ (ed) Salmonid age at maturity. Department of Fisheries and Oceans, Ottawa, p 39-52

Healey MC (1991) Life history of chinook salmon (Oncorhynchus tshawytscha). In: Groot C, Margolis L (eds) Pacific salmon life histories. UBC Press, Vancouver, p 313-393

Heard WR (1991) Life history of pink salmon (Oncorhynchus gorbuscha). In: Groot C, Margolis L (eds) Pacific salmon life histories. UBC Press, Vancouver, p 121-230

Heimlich-Boran J (1986) Fishery correlations with the occurrence of killer whales in greater Puget Sound. In: Kirkevold BC, Lockard JS (eds) Behavioral biology of killer whales. Alan R. Liss, New York, p 113-131

Heimlich-Boran JR (1988) Behavioral ecology of killer whales (Orcinus orca) in the Pacific Northwest. Can J Zool 66: $565-578$

Hoelzel AR (1993) Foraging behaviour and social group dynamics in Puget Sound killer whales. Anim Behav 45: 581-591

Hoelzel AR, Dahlheim M, Stern SJ (1998) Low genetic variation among killer whales (Orcinus orca) in the eastern North Pacific, and genetic differentiation between foraging specialists. J Hered 89:121-128

Jacobsen JK (1986) The behavior of Orcinus orca in the Johnstone Strait, British Columbia. In: Kirkevold BC, Lockard JS (eds) Behavioral biology of killer whales. Alan R. Liss, New York, p 135-185

Jefferson TA, Stacey PF, Baird RW (1991) A review of killer whale interactions with other marine mammals: predation to co-existence. Mammal Rev 21:151-180

Karanth KU, Sunquist ME (1995) Prey selection by tiger, leopard and dhole in tropical forests. J Anim Ecol 64: $439-450$ 
Kuhn BR (1988) The MRP-reporter program: a data extraction and reporting tool for the mark recovery program database. Can Tech Rep Fish Aquat Sci 1625

Lawson JW, Anderson JT, Dalley EL, Stenson GB (1998) Selective foraging by harp seals Phoca groenlandica in nearshore and offshore waters of Newfoundland, 1993 and 1994. Mar Ecol Prog Ser 163:1-10

Lopez JC, Lopez D (1985) Killer whales (Orcinus orca) of Patagonia, and their behavior of intentional stranding while hunting nearshore. J Mammal 66:181-183

Mann J (1999) Behavioral sampling methods for cetaceans: a review and critique. Mar Mamm Sci 15:102-122

Martinez DR, Klinghammer E (1970) The behavior of the whales, Orcinus orca: a review of the literature. Z Tierpsychol 27:828-839

Matkin CO, Saulitis EL (1994) Killer whale (Orcinus orca) biology and management in Alaska. Contract No. T75135023, Marine Mammal Commission, Washington, DC

Mizroch SA, Rice DW (2006) Have North Pacific killer whales switched prey species in response to depletion of the great whale populations? Mar Ecol Prog Ser 310:235-246

Nichol LM, Shackleton DM (1996) Seasonal movements and foraging behaviour of northern resident killer whales (Orcinus orca) in relation to the inshore distribution of salmon (Oncorhynchus spp.) in British Columbia. Can J Zool 74:983-991

Olesiuk PF, Bigg MA, Ellis GM (1990) Life history and population dynamics of resident killer whales (Orcinus orca) in the coastal waters of British Columbia and Washington State. Rep Int Whal Comm Spec Issue 12:209-242

Osborne RW (1999) A historical ecology of Salish Sea 'resident' killer whales (Orcinus orca): with implications for management. PhD dissertation, University of Victoria, Victoria

Pitman RL, Ensor P (2003) Three forms of killer whales (Orcinus orca) in Antarctic waters. J Cetacean Res Manag 5: 131-139

Quinn TP (2005) The behavior and ecology of Pacific salmon and trout. UBC Press, Vancouver

Rendell LE, Whitehead H (2001) Culture in whales and dolphins. Behav Brain Sci 24:309-331

Ricker WE (1980) Changes in the age and size of chum salmon (Oncorhynchus keta). Can Tech Rep Fish Aquat Sci 930

Riddell B (2004) Pacific salmon resources in central and north coast British Columbia, Pacific Fisheries Resource Conservation Council, Vancouver (also available at www.fish.bc.ca/)

Ryall P, Murray C, Palermo V, Bailey D, Chen D (1999) Status of clockwork chum salmon stock and review of the clock-

Editorial responsibility: Howard I. Browman (Associate Editor-in-Chief), Storebø, Norway work management strategy. CSAS Rep No. 99/169, Fisheries and Oceans Canada, Ottawa (also available at www.dfo-mpo.gc.ca/CSAS/)

Salo EO (1991) Life history of chum salmon (Oncorhynchus keta). In: Groot C, Margolis L (eds) Pacific salmon life histories. UBC Press, Vancouver, p 233-309

Sandercock FK (1991) Life history of coho salmon (Oncorhynchus kisutch). In: Groot C, Margolis L (eds) Pacific salmon life histories. UBC Press, Vancouver, p 397-445

Saulitis E, Matkin C, Barrett-Lennard L, Heise K, Ellis G (2000) Foraging strategies of sympatric killer whale (Orcinus orca) populations in Prince William Sound, Alaska. Mar Mamm Sci 16:94-109

Scheel D (1993) Profitability, encounter rates, and prey choice of African lions. Behav Ecol 4:90-97

Similä T, Ugarte F (1993) Surface and underwater observations of cooperatively feeding killer whales in northern Norway. Can J Zool 71:1494-1499

Similä T, Holst JC, Christensen I (1996) Occurrence and diet of killer whales in northern Norway: seasonal patterns relative to the distribution and abundance of Norwegian spring-spawning herring. Can J Fish Aquat Sci 53: 769-779

Springer AM, Estes JA, van Vliet GB, Williams TM, Doak DF, Danner EM, Forney KA, Phister B (2003) Sequential megafaunal collapse in the North Pacific Ocean: an ongoing legacy of industrial whaling? Proc Natl Acad Sci USA 100:12223-12228

Stansby ME (1976) Chemical characteristics of fish caught in the northeast Pacific Ocean. Mar Fish Rev 38:1-11

Stephens DW, Krebs JR (1986) Foraging theory. Princeton University Press, Princeton, NJ

Tollit, D, Greenstreet SPR, Thompson PM (1997) Prey selection by harbour seals, Phoca vitulina, in relation to variations in prey abundance. Can J Zool 75:1508-1518

Wiles GJ (2004) Washington State status report for the killer whales. Washington Department of Fish and Wildlife, Olympia, WA (also available at http://wdfw.wa.gov/)

Winship AJ, Trites AW (2003) Prey consumption of Steller sea lions (Eumetopias jubatus) off Alaska: how much prey do they require? Fish Bull (Wash DC) 101:147-163

Withler RE, Candy JR, Beacham TD, Miller KM (2004) Forensic DNA analysis of Pacific salmonid samples for species and stock identification. Environ Biol Fish 69: 275-285

Wydoski RS, Whitney RR (2003) Inland fishes of Washington. University of Washington Press, Seattle

Yano K, Dahlheim ME (1995) Behavior of killer whales Orcinus orca during longline fishery interactions in the southeastern Bering Sea and adjacent waters. Fish Sci 61: $584-589$

Submitted: September 12, 2005; Accepted: November 15, 2005 Proofs received from author(s): June 16, 2006 